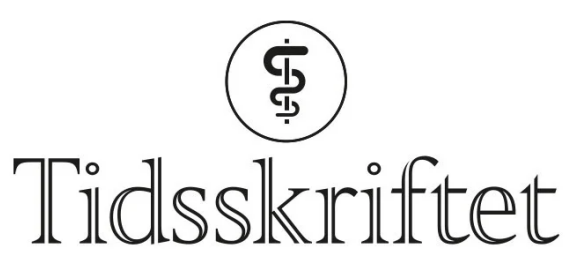

DEN NORSKE LEGEFORENING

\title{
Opiat eller opioid?
}

SPRÅKSPALTEN

\section{ANDREAS AUSTGULEN WESTIN}

Andreas Austgulen Westin (f. 1977) er lege i spesialisering ved Avdeling for klinisk farmakologi. Email: andreas.westin@legemidler.no

St. Olavs hospital

\section{ELIN JOHANNE HANSTEEN STR $\varnothing \mathrm{M}$}

Elin Johanne Hansteen Strøm (f. 1970) er lege ved Lade Behandlingssenter Blå Kors. Lade Behandlingssenter Blå Kors

\section{LARS SLØRDAL}

Lars Slørdal (f. 1955) er spesialist i klinisk farmakologi og professor. Institutt for laboratoriemedisin, barne- og kvinnesykdommer Norges teknisk-naturvitenskaplige universitet og Avdeling for klinisk farmakologi St. Olavs hospital

\section{I både medisinsk og allmenn litteratur benyttes ordene opioid og opiat ofte vekselvis, som om de var synonyme begreper. Det er de ikke.}

Ordene «opioid» og «opiat» stammer fra ordet «opium». Opium er navnet på den melkehvite plantesaften (av gresk: opos = saft) som siver ut når man skjærer et snitt i en moden opiumsvalmue (fig 1 ). 


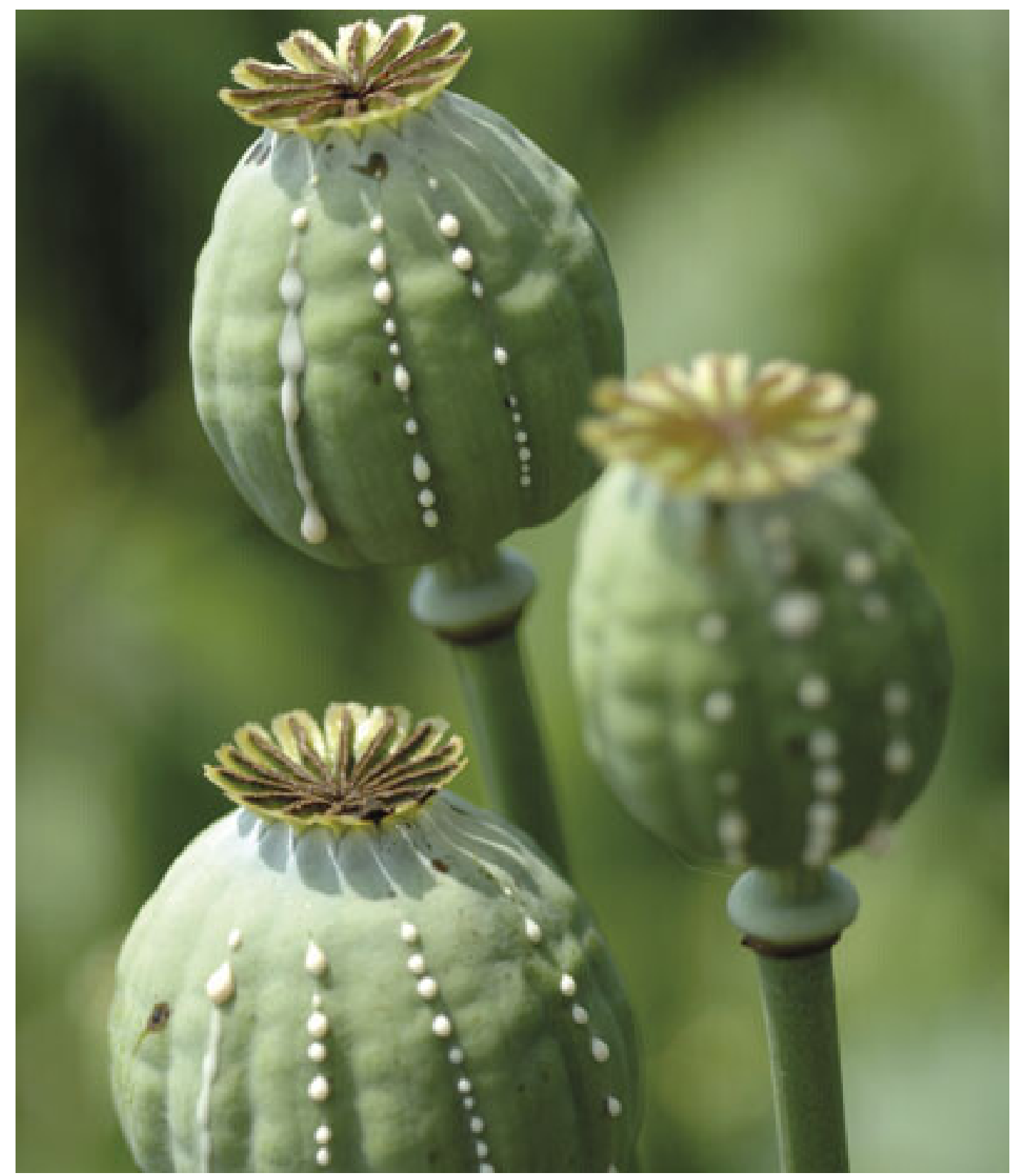

Figur 1 Opiumsvalmuen (Papaver somniferum) med den melkehvite plantesaften opium. Istockphoto

\section{Hva er et opiat?}

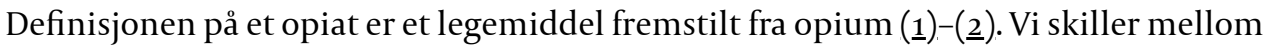
naturlige og semisyntetiske opiater. De naturlige opiatene (morfin, kodein, tebain, noskapin og papaverin) er bestanddeler i plantesaften opium, mens de semisyntetiske opiatene (for eksempel heroin, etylmorfin, oksykodon og buprenorfin) ikke finnes i opium, men kan fremstilles fra de naturlige opiatene. Dette betyr rent definisjonsmessig at et opiat er et legemiddel som opphavsmessig - direkte eller indirekte - kan spores tilbake til opiumsvalmuen.

\section{Hva er et opioid?}

Som endingen -oid tilsier, er opioider stoffer som likner på opium, eller nærmere bestemt: stoffer med morfinliknende effekt. Begrepet er altså en farmakologisk klassifisering, definert ut fra påvirkning av kroppens opioidreseptorer, uavhengig av stoffets kjemiske opphav

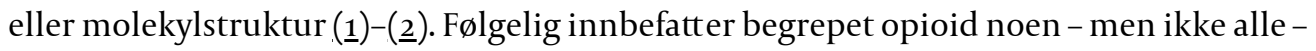


opiatene, og i tillegg en rekke helsyntetiske opioider (som fentanyl, ketobemidon og metadon) samt kroppens egne opioide peptider (endorfiner). Noen kilder inkluderer også opioidantagonistene nalokson og naltrekson (3).

\section{Alvorlige misforståelser}

Som det fremgår av definisjonene over, og som vist i figur 2, har begrepene opiat og opioid delvis overlappende innhold. Dette kan lett skape forvirring og misforståelser. Til og med i Norsk medisinsk ordbok fremstår dette uklart. I siste utgave kan man lese at et opiat er «morfin, kodein og andre stoff med lignande verknad framstilte frå opium» (3). Her må «med lignande verknad» strykes for at det skal bli riktig. Når man har å gjøre med to ikkesynonyme betegnelser innenfor én og samme gruppe substanser, blir det ekstra viktig å holde tunga rett i munnen. Ved sammenblanding kan alvorlige feil lett oppstå, ikke minst i forbindelse med rusmiddeltesting: Inntak av for eksempel ketobemidon, fentanyl eller metadon vil ikke kunne påvises dersom man utfører eksklusive opiatanalyser (fig 2). Det er publisert flere kasuistikker der slike misforståelser har ført til uberettiget mistanke om dårlig etterlevelse og videresalg av legemidler $(\underline{2}, \mathbf{4}$.).

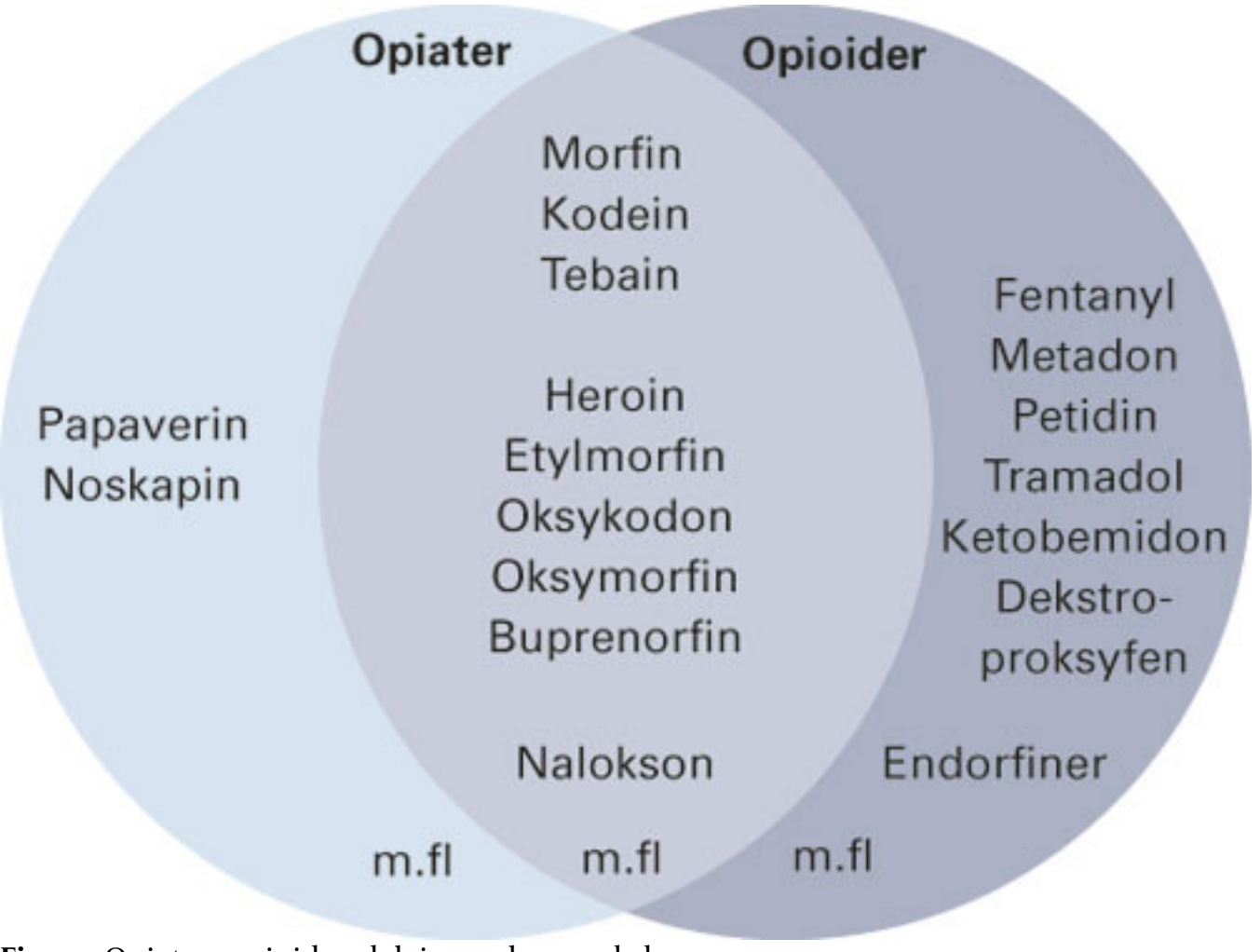

Figur 2 Opiat og opioid er delvis overlappende begreper

\section{Hvilket begrep skal vi bruke?}

I klinisk virksomhet trenger vi terminologi som ikke kan misforstås. Moderne teknologi har gjort begrepet opiat avleggs og uklart, siden det i dag er mulig å fremstille også de naturlig forekommende opiatene syntetisk (5). Allerede i 1984 erklærte The Lancet at begrepet opiat var utgått på dato. Enda lenger er det siden det farmakologiske referanseverket Goodman \& Gilman konsekvent rensket bort begrepet opiat fra sine velrenommerte sider $(\mathbf{1}, 5)$.Historien har altså kåret opioid til vinneren i begrepsdebatten. Likevel bruker vi fortsatt begrepet opiat. Man kan ennå lese artikkeltitler som inneholder ordene opiatreseptor, opiatsubstitusjon og opiatavhengighet, trass i at prefikset opioidi slike sammenhenger hadde vært mer presist. Et friteksts $ø \mathrm{k}$ i Medline i tidsrommet fra nevnte kommentar i The Lancet (mars 1984) til april 2011 ga ca. 84 ooo treff på ordet «opioid 
\%», men også ca. 12 ooo treff på ordet «opiate\%». Tidsskriftet er intet unntak, med henholdsvis 260 og 153 artikkeltreff på fritekstsøkeordene «opioid\%» og opiat\%» siden 2000. Søk på begge begrepene i én og samme artikkel ga 49 treff.

Man skal kanskje ikke argumentere for å «avskaffe» ord; språk- og nyanserikdom er avhengig av en velfylt verktøykasse. Likevel synes tiden og teknologiutviklingen å ha løpt fra opiatbegrepet, som både er uklart, overflødig og kan gi opphav til misforståelser - som igjen kan ha alvorlige følger for enkeltpasienter. Vi mener det er på høy tid å kassere ordet.

\section{LITTERATUR}

1. Gutstein H, Akil H. Opioid analgesics. I: Hardman J, Limbird L, Gilman A, red. The pharmacological basis of therapeutics. 10. utg. Columbus, OH: The McGraw-Hill Companies, 2008: 547-6o.

2. Reisfield GM, Bertholf RL, Wilson GR. Opiates and opioids: what a difference a name makes. J Opioid Manag 2007; 3: 179-80.

3. Øyri A. Norsk medisinsk ordbok. 8. utg. Oslo: Det Norske Samlaget, 2007.

4. Von Seggern RL, Fitzgerald CP, Adelman LC et al. Laboratory monitoring of OxyContin (oxycodone): clinical pitfalls. Headache 2004; 44: 44-7.

5. Opiates or opioids? Lancet 1983; 1: 687.

Publisert: 1. juli 2011. Tidsskr Nor Legeforen. DOI: 10.4045/tidsskr.11.0465

Mottatt 5.4. 2011og godkjent 24.5. 2011. Medisinsk redaktør Raida Ødegaard.

(C) Tidsskrift for Den norske legeforening 2023. Lastet ned fra tidsskriftet.no 26. april 2023. 